\title{
Evaluasi Analitik Hematology Analyzer Diatron Abacus 3 Pada Parameter Hematologi Rutin Di Laboratorium Hematologi Poltekkes Kemenkes Kalimantan Timur
}

\author{
Suryanata Kesuma, Mahdiah Syumarliyanty, Agus Rudi Hartono
}

Jurusan Teknologi Laboratorium Medis, Poltekkes Kemenkes Kaltim, Jalan Kurnia Makmur No 64, Kota Samarinda, 75123

e-mail : suryanatakesuma@gmail.com

Tanggal Submit: 19 November 2020

Tanggal Review: 22 Februari 2021

Tanggal Publish Online: 18 Juni 2021

\begin{abstract}
Entering the era of globalization, manual tools in clinical laboratories have been replaced by full automatic devices. One of them is the Diatron Abacus Hematology analyzer 3. A relatively new hematology analyzer is required for analytical evaluation. Analytical evaluation is an evaluation of Diatron Abacus 3 on Sysmex KX 21 as a standard in RSUD I.A Moeis Samarinda, and it is very important to do this to assess the performance of the tool. Analytical evaluation is done by determining the value of accuracy, precision, and total error and linearity of measurement results from routine hematological examination parameters, which are erythrocytes, leukocytes, platelets, hemoglobin, and hematocrit. To determine the results of the hematology analyzer evaluation of Abacus 3 Diatron Analyzers on Routine Hematology Parameters in the Hematology Laboratory of the Health Ministry of Health, East Kalimantan. This type of research is observational descriptive, using a total sampling technique, and a sample of 40 complete K3EDTA blood specimens. Data processing using Microsoft Excel and SPSS 20 applications, analyzed using descriptive statistics. The observations were still included in the criteria for acceptance, accuracy or inaccuracy (d\%) in erythrocytes $1.8 \%$, leukocytes $8.0 \%$, platelets $-5.3 \%$, hemoglobin $2.3 \%$ and hematocrit $-1.7 \%$; Precision or impression (CV\%) in erythrocytes $4.2 \%$, leukocytes $11.1 \%$, platelets $6 \%$, hemoglobin $3.9 \%$ and hematocrit 4.5\%; Total errors in erythrocytes were $8.7 \%$, leukocytes $17.9 \%$, platelets $23.6 \%$, hemoglobin $8.8 \%$ and hematocrit 9.1; Linearity of the measurement results against the routine hematological cell count values performed using Abacus 3 and Sysmex KX 21 has a positive relationship. Acceptance values are still included in the LOA on all parameters examined and still meet the criteria; the accuracy/bias value is smaller than the true value of the parameter being examined, except for leukocytes, which is greater; the precision on the five parameters is greater than the CV\% Abacus 3 insert kit; The total error obtained by the TE value is greater than the TEA in the parameters examined, except for smaller platelets; Linearity of the measurement results against the calculated hematology cell routine values performed using Abacus 3 and Sysmex KX 21 have a positive relationship, meaning an increase in measurement values using Abacus 3 is followed by an increase in measurement values using Sysmex KX 21.
\end{abstract}

Keywords: Analytical Evaluation, Hematology Analyzer, Hematology Routine 


\section{PENDAHULUAN}

Memasuki era globalisasi, dunia kesehatan mengalami kemajuan yang pesat, salah satunya yaitu dalam bidang laboratorium. Inovasi baru dengan penggunaan alat-alat yang full automatic telah menggantikan alat-alat manual. Setiap produk dan jasa yang dihasilkan suatu laboratorium harus memenuhi suatu jaminan mutu secara totalitas. Tugas dan tanggung jawab dari laboratorium sangat penting dalam menunjang pelayanan medis di rumah sakit yakni dalam penegakan diagnosa, pengobatan lanjut, monitoring, keputusan rawat inap serta pasien yang pulang (Nirwani, Hartiti, and Faruq 2018).

Laboratorium

kesehatan merupakan salah satu unit penunjang medis, sehingga diharapkan dapat memberikan informasi yang teliti dan akurat tentang aspek laboratoris terhadap spesimen atau sampel dengan pengujian yang dilakukan di laboratorium. Jaminan mutu merupakan salah satu tahapan yang harus dilakukan oleh seorang ahli teknologi laboratorium medis, karena hal tersebut adalah suatu tahapan untuk menjamin ketepatan dan ketelitian suatu hasil pemeriksaan. Jaminan mutu juga dapat dilakukan untuk mengevaluasi suatu aspek teknis pengujian atau kalibrasi. Hal ini dapat diartikan sebagai pengendalian, pemantauan, dan pemeriksaan yang dilakukan untuk memastikan bahwa sistem manajemen mutu berjalan dengan benar (Ayuningtyas 2018; Departemen Kesehatan RI 2008).

Pemeriksaan darah rutin yang biasa dilakukan di suatu laboratorium rumah sakit maupun klinik merupakan pemeriksaan yang sering diminta oleh klinisi. Hasil pemeriksaantersebut digunakan sebagai pedoman untuk terapi lebih lanjut. Salah satu alat yang digunakan untuk pemeriksaan tersebut yaitu hematology analyzer. Hematologi analyzer merupakan alat penghitung otomatis sel darah lengkap yang terdiri dari beberapa parameter yang dapat diukur secara bersamaan (Ayuningtyas 2018; Verbrugge and Huisman 2015).

Pedoman standar CLSI dan ICSH tentang verifikasi terhadap hematology analyzer dikatakan bahwa sangat penting untuk melakukan evaluasi terhadap Hematology analyzer yang tergolong baru. Evaluasi tersebut dilakukan untuk menilai performa kinerja dari Hematology analyzer dengan membandingkan dengan Hematology analyzer yang sudah terstandar untuk memastikan hasil pasien tidak terpengaruh. Standar CLSI mencantumkan minimum poin validasi dilakukan dengan membandingkan 
verifikasi mode dengan spesifikasi pabrikan (Verbrugge and Huisman 2015).

Kualitas pelayanan laboratorium di rumah sakit dapat dilihat dari pemantapan mutu laboratorium rumah sakit tersebut. Salah satu aspek pemantapan mutu yang utama yaitu akurasi dan presisi suatu tinstrumen laboratorium yang digunakan. Oleh karena itu, tenaga laboratorium profesional harus mampu melakukan pemantapan mutu dan melakukan evaluasi terhadap instrumen di laboratorium. Jumlah pasien yang terus meningkat pada suatu pelayanan rumah sakit, dituntut tetap memiliki kualitas pelayanan dan baik serta prasarana yang baik (Nirwani, Hartiti, and Faruq 2018). Sebagai seorang calon tenaga laboratorium medis diharapkan dapat mengetahui tentang pemantapan mutu laboratorium salah satunya yaitu quality control serta pemeliharaan alat, kalibrasi, evaluasi kinerja alat/metode pemeriksaan laboratorium maupun adanya kerusakan pada alat tersebut, sehingga dapat mengetahui dan memahami jika ada penyimpangan hasil pemeriksaan laboratorium yang berefek pada kualitas pelayanan laboratorium.

Laboratorium Hematologi Poltekkes Kemenkes Kalimantan Timur memiliki hematology analyzer baru yaitu Diatron Abacus 3. Alat tersebut digunakan oleh mahasiswa dalam melakukan pembelajaran praktik serta penelitian di laboratorium. Selain itu, dalam beberapa tahun ke depan Poltekkes Kemenkes akan menjadi institusi Badan Layanan Umum sehingga ada peluang laboratorium hematologi menerima spesimen pemeriksaan dari masyarakat/ pasien untuk tujuan diagnosis. Oleh karena itu hasil pemeriksaan hematologi dari Hematology analyzer Diatron Abacus 3 harus reliabel dan dapat dipercaya layaknya alat yang ada di laboratorium rumah sakit. Tujuan penelitian ini untuk mengetahui hasil evaluasi analitik Hematology analyzer Diatron Abacus 3 pda parameter hematologi rutin di Laboratorium Hematologi Poltekkes Kemenkes Kalimantan Timur.

\section{METODE PENELITIAN}

Jenis penelitian ini menggunakan metode deskriptif untuk mengetahui perhitungan akurasi, presisi dan total error hematology analyzer Diatron Abacus 3 di laboratorium Poltekkes Kemenkes Kalimantan Timur. Rancangan penelitian ini adalah rancangan observasional yaitu berupa pemeriksaan secara laboratorium yang dilakukan melalui pengukuran hematologi rutin pada parameter 
leukosit, eritrosit, hematokrit, haemoglobin, dan trombosit dengan menggunakan Hematology Analyzer Diatron Abacus 3 dan Sysmex KX 21 digunakan sebagai metode standar dari pemeriksaan. Teknik pengambilan sampel adalah total sampling, sesuai dengan westragard dalam melakukan evaluasi analitik sampel yang dibutuhkan sejumlah minimal 40 sampel berupa spesimen darah lengkap $\mathrm{K}_{3}$ EDTA dan diperiksa secara duplo. Kriteria inklusi penelitian ini adalah spesimen darah lengkap dengan antikoagulan $\mathrm{K}_{3}$ EDTA pada pasien yang melakukan pemeriksaan di laboratorium RSUD I.A Moeis, Samarinda. Kriteria ekslusi penelitian ini adalah spesimen darah lengkap yang hemolisis, ada bekuan, dan terlalu encer. Evaluasi analitik ditentukan dengan menghitung presisi, akurasi dan total error pada pemeriksaan hematologi rutin dengan menggunakan Hematology analyzer Diatron Abacus 3. Data primer yang diperoleh dari hasil pemeriksaan hematologi rutin kemudian di catat dan dikumpulkan, lalu diolah menggunakan aplikasi Microsoft excel dan SPSS 20.

Analisis bland altman diperoleh dari selisih (difference) dengan nilai rata-rata (mean) yang diukur dengan Sysmex KX 21 dan Abacus 3 dengan LOA (Limit of Agreement) $95 \%$.
Akurasi didapatkan dengan mengukur selisih nilai pada parameter yang akan dihitung dan dibagi dengan nilai ratarata pengukuran pada Abacus 3 terhadap Sysmex KX 21, selanjutnya dikalikan $100 \%$. Pengukuran nilai pada parameter tersebut menggunakan Abacus 3 dan dilakukan dengan dua kali pengukuran, disajikan pada dalam bentuk tabel.

\section{HASIL PENELITIAN}

Penelitian mengenai Evaluasi Analitik Hematology analyzer Diatron Abacus 3 di Laboratorium Poltekkes Kemenkes Kalimantan Timur telah dilaksanakan di Laboratorium Hematologi Jurusan Teknologi Laboratorium Medis Poltekkes Kemenkes Kalimantan Timur. Pemeriksaan yang dijadikan gold standart menggunakan alat Hematology analyzer Sysmex $\mathrm{KX} \quad 21$ di Laboratorium Rumah Sakit I.A Moeis dengan total sampel sebanyak 40 spesimen darah. Sebelum dilakukan pemeriksaan Hematology analyzer Diatron Abacus 3 dan Sysmex KX 21 telah dilakukan Quality Control terlebih dahulu dengan hasil kontrol dalam kondisi baik.

Analisis Bland Altman merupakan metode statistik untuk menilai keberterimaan (agreement) antara dua metode pengukuran klinis. 
Hasil analisis dari selisih (difference) dengan nilai rata-rata (mean) yang diukur dengan Sysmex KX 21 dan Abacus 3 dengan LOA (Limit of Agreement) 95\%. Dari grafik yang diperoleh akan digunakan untuk menilai kesesuaian dari dua pengukuran dengan perbedaan rerata pengukuran yang menggambarkan bias yang mungkin terjadi pada dua pengukuran. Presisi didapatkan dengan menghitung standar deviasi nilai pada parameter yang dihitung dan dibagi dengan nilai ratarata hasil pemeriksaan berulang pada

a)

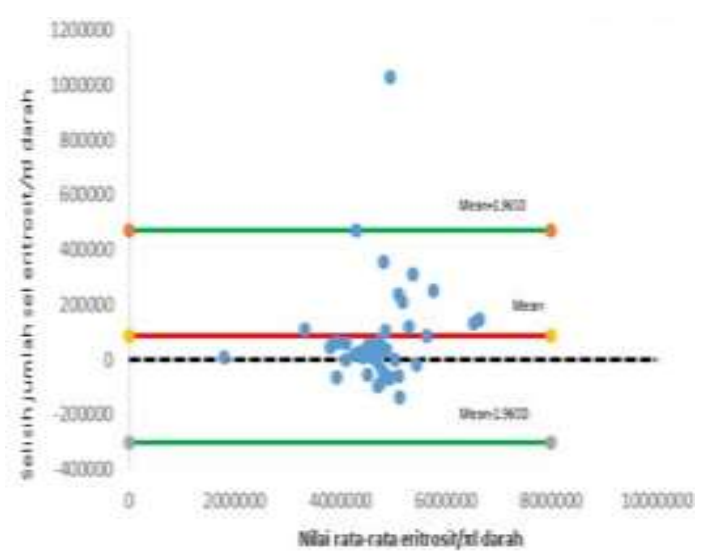

c)

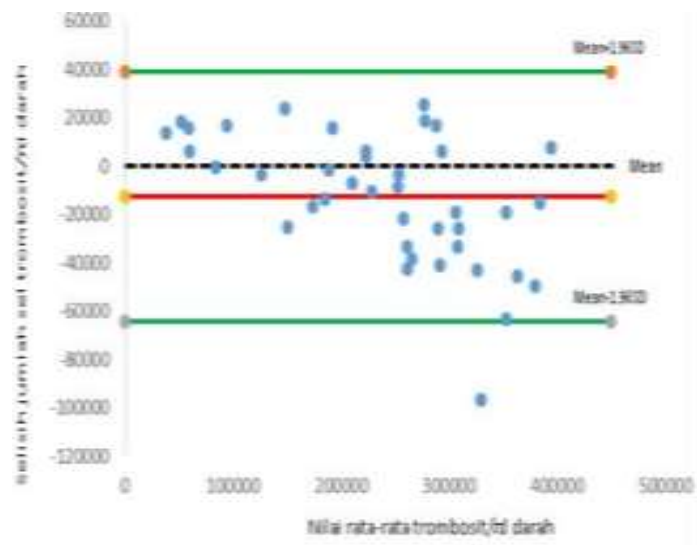

abacus 3 terhadap Sysmex KX 21, selanjutnya dikalikan $100 \%$. Presisi nilai pada tiap parameter, disajikan pada tabel 2. Total error didapatkan dengan menghitung bias (d\%) selanjutnya ditambah dengan 1,65 dikalikan dengan nilai CV\%. Nilai TE akan dibandingkan dengan nilai Total Error Allowable (TEA) pada tiap parameter. Nilai TE disajikan pada tabel 3. Linearitas digunakan untuk mengetahui hubungan antara Abacus 3 dengan Sysmex KX 21 dengan persamaan garis $\mathrm{y}=\mathrm{ax}+\mathrm{b}$ dan dengan mengetahu $\mathrm{R}^{2}$ serta $\mathrm{R}$.

b)

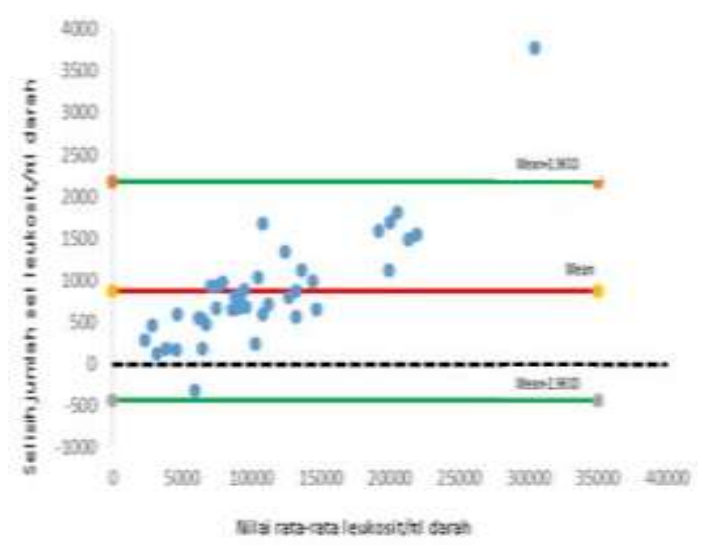

d)

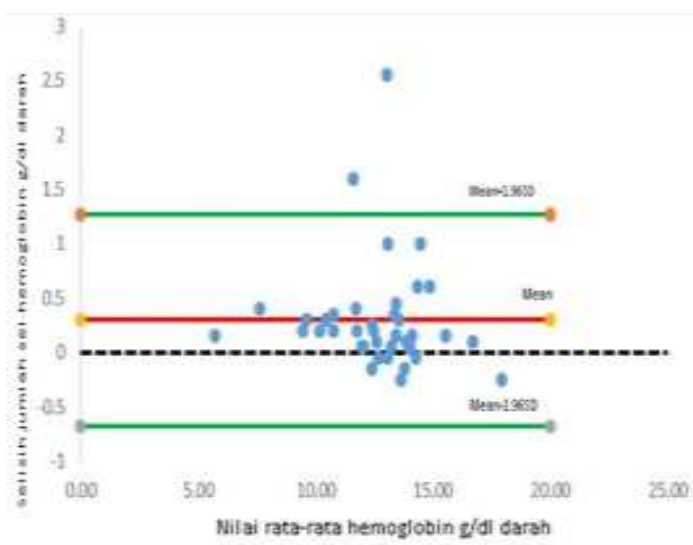


e)

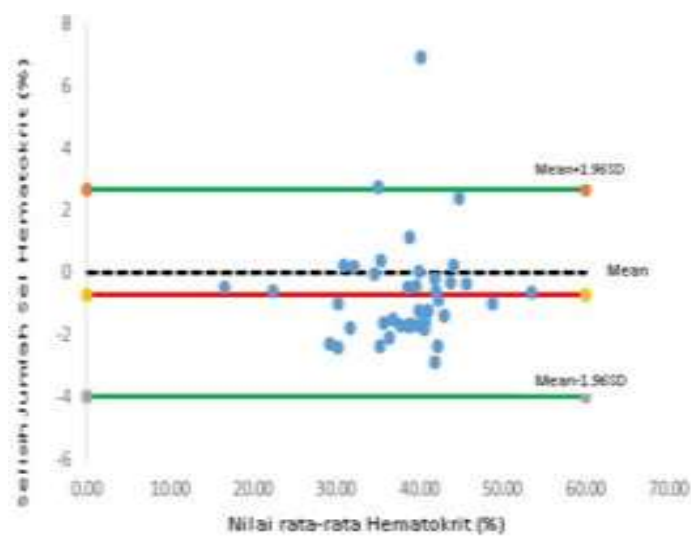

Gambar 1. Grafik Bland Altman Abacus 3 terhadap Sysmex KX 21 a) eritrosit, b) leukosit, c) trombosit, d) hemoglobin, e) hematokrit

Grafik 1.a. menggambarkan hubungan antara selisih pengukuran nilai eritrosit dengan menggunakan Abacus 3 dan Sysmex KX 21 terhadap rata-ratanya. Diperoleh bias atau mean difference sebesar 85000, Upper limit sebesar 470315.76 dan lower limit sebesar -300315.76. Berdasarkan grafik terlihat bahwa terdapat satu pengamatan atau titik dalam grafik yang berada diluar Upper Limit yang berarti pengamatan tersebut dianggap outliers.

Gambar 1.b menggambarkan hubungan antara selisih pengukuran nilai leukosit dengan menggunakan Abacus 3 dan Sysmex KX 21 terhadap rata-ratanya. Diperoleh bias atau mean difference sebesar 873.88, Upper limit sebesar 2171.54 dan lower limit sebesar -423.79. Berdasarkan grafik terlihat bahwa terdapat satu pengamatan atau titik dalam grafik yang berada diluar Upper Limit yang berarti pengamatan tersebut memiliki perbedaan dengan pengamatan lainnya atau dianggap outliers.

Gambar 1.c menggambarkan hubungan antara selisih pengukuran nilai trombosit dengan menggunakan Abacus 3 dan Sysmex KX 21 terhadap rata-ratanya. Diperoleh bias atau mean difference sebesar -12687.5, Upper limit sebesar 38990.52 dan lower limit sebesar -64365.52. Berdasarkan grafik terlihat bahwa terdapat satu pengamatan atau titik dalam grafik yang berada diluar Lower Limit yang berarti pengamatan tersebut memiliki perbedaan dengan pengamatan lainnya atau dianggap outliers.

Gambar 1.d menggambarkan hubungan antara selisih pengukuran nilai hemoglobin dengan menggunakan Abacus 3 dan Sysmex KX 21 terhadap rata-ratanya. Diperoleh bias atau mean difference sebesar 0.3, Upper limit sebesar 1.27 dan lower limit sebesar 0.68. Berdasarkan grafik terlihat bahwa 
terdapat dua pengamatan atau titik dalam grafik yang berada diluar Upper Limit yang berarti pengamatan tersebut memiliki perbedaan dengan pengamatan lainnya atau dianggap outliers.

Gambar 1.e menggambarkan hubungan antara selisih pengukuran nilai hematokrit dengan menggunakan Abacus 3 dan Sysmex KX 21 terhadap rata-ratanya. Diperoleh bias atau mean difference sebesar -0.7, Upper limit sebesar 2.68 dan lower limit sebesar 3.99. Berdasarkan grafik terlihat bahwa terdapat satu pengamatan atau titik dalam grafik yang berada diluar Upper Limit yang berarti pengamatan tersebut memiliki perbedaan dengan pengamatan lainnya atau dianggap outliers.

Tabel 1 Akurasi nilai parameter Hematologi rutin Alat Abacus 3 terhadap Sysmex KX 21

\begin{tabular}{lcc}
\hline Parameter & $\mathrm{d} \%$ Hitung & $\mathrm{d} \%$ pada Kit Insert Abacus 3 \\
\hline Eritrosit & 1,8 & 6,0 \\
Leukosit & 8,0 & 6,0 \\
Trombosit & $-5,3$ & 8,0 \\
Hemoglobin & 2,3 & 6,0 \\
Hematokrit & $-1,7$ & - \\
\hline
\end{tabular}

Sumber : Data Primer

Tabel 1 menunjukkan bahwa d\% hitung eritrosit $1,8 \%$, trombosit $-5,3 \%$, hemoglobin $2,3 \%$ dan hematokrit $-1,7 \%$ lebih kecil dibandingkan $\mathrm{d} \%$ pada kit insert Abacus 3, kecuali leukosit 8,0\% lebih besar.

Tabel 2 Presisi nilai parameter Hematologi rutin Alat Abacus 3 terhadap Sysmex KX 21

\begin{tabular}{lcc}
\hline Parameter & CV $(\%)$ Hitung & CV $(\%)$ pada Kit Insert Abacus 3 \\
\hline Eritrosit & 4,2 & $<2,5$ \\
Leukosit & 6,0 & $<4,0$ \\
Trombosit & 11,1 & $<7,0$ \\
Hemoglobin & 3,9 & $<2,4$ \\
Hematokrit & 4,5 & - \\
\hline
\end{tabular}

Sumber : Data Primer

Tabel 2 menunjukkan bahwa $\mathrm{CV}(\%)$ hitung eritrosit 4,2\%, leukosit $6,0 \%$, trombosit $11,1 \%$, hemoglobin $3,9 \%$ dan hematokrit $4,5 \%$ lebih besar dibandingkan CV pada kit insert Abacus 3. 
Tabel 3 Nilai Total Error parameter hematologi rutin Alat Abacus 3 terhadap Sysmex

\begin{tabular}{lcc}
\multicolumn{3}{c}{ KX 21 } \\
\hline Parameter & TE (\%) Hitung & TEA(\%) berdasarkan CLIA \\
\hline Eritrosit & 8,7 & $\pm 6,0$ \\
Leukosit & 17,9 & \pm 15 \\
Trombosit & 23,6 & \pm 25 \\
Hemoglobin & 8,8 & \pm 7 \\
Hematokrit & 9,1 & \pm 6 \\
\hline
\end{tabular}

Sumber : Data Primer 2019

Tabel 3 menunjukkan bahwa TE hitung lebih besar dari TEA pada parameter eritrosit $8,7 \%$, leukosit $17,9 \%$, hemoglobin $8,8 \%$ dan hematokrit $9,1 \%$, sedangkan untuk parameter trombosit TE hitung lebih kecil dari TEA yaitu 23,6\%.

a)

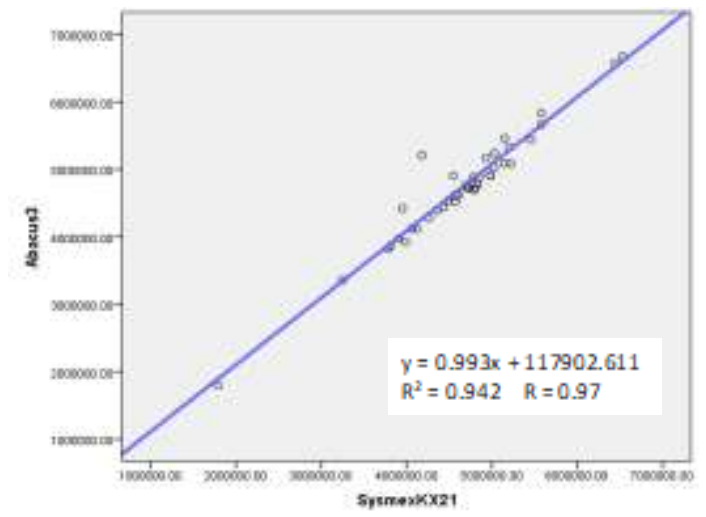

c)

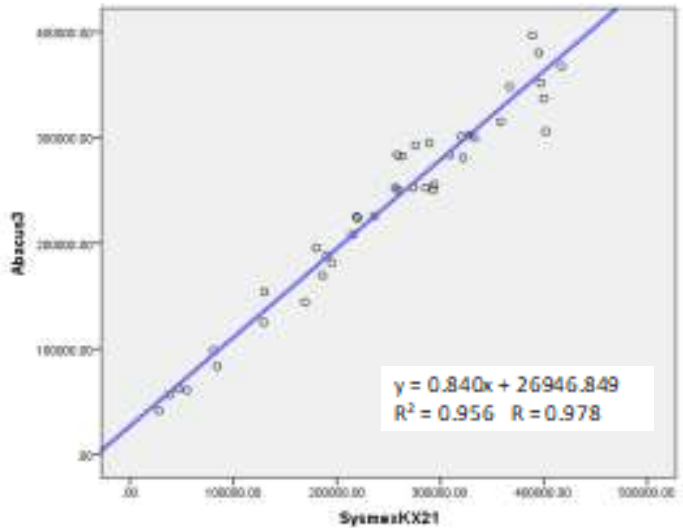

Linearitas digunakan untuk mengetahui hubungan antara dua metode pengukuran dengan dilakukannya analisis regresi linear hasil pengukuran pada parameter hematologi rutin dengan menggunakan Hematology analyzer Abacus 3 terhadap Sysmex KX 21

b)

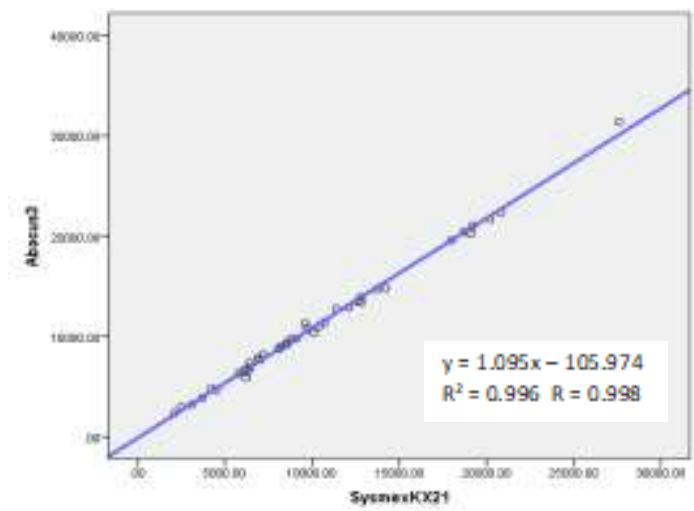

d)

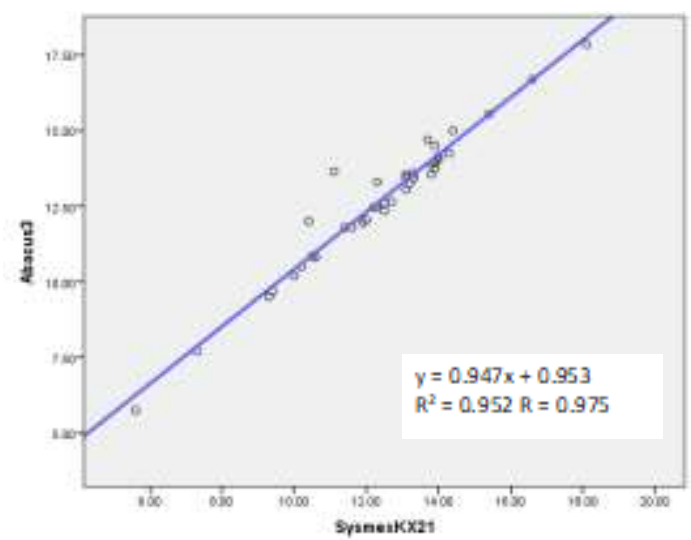


e)

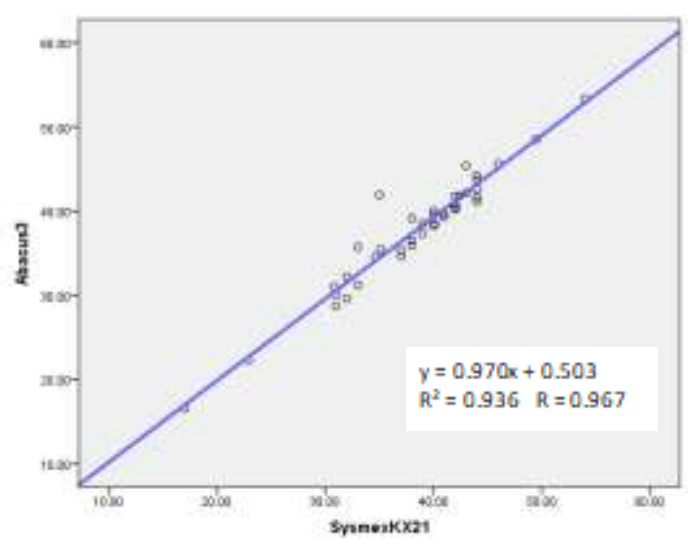

Gambar 2. Grafik Linearitas Abacus 3 terhadap Sysmex KX 21

a) eritrosit, b) leukosit, c) trombosit, d) hemoglobin, e) hematokrit

Evaluasi analitik terhadap hematology analyzer meliputi akurasi, presisi dan total error. Akurasi merupakan kemampuan untuk mengukur dengan tepat sesuai dengan nilai benar (true value) atau nilai yang dapat diterima (accepted true value) serta merupakan kesepakatan kedekatan antara pengukuran. Akurasi dapat ditetapkan dengan mengukur atau memeriksa kadar bahan kontrol atau sampel menggunakan metode standar. Dalam penelitian ini, peneliti menggunakan alat sysmex $\mathrm{KX} \quad 21$ sebagai standar dari pemeriksaan. Akurasi dapat dinyatakan dalam ukuran inakurasi. Inakurasi alat dapat dilakukan dengan melakukan pengukuran terhadap bahan kontrol atau nilai yang telah diketahui kadarnya. Perbedaan hasil dengan nilai target yang telah diketahui merupakan indikator inakurasinya. Nilai bias dapat dinyatakan dalam nilai positif atau negatif. Nilai positif menunjukkan nilai yang lebih tinggi dari nilai benar, sedangkan nilai negatif menunjukkan nilai yang lebih rendah dari nilai benar. Pemeriksaan yang memiliki nilai bias yang besar atau akurasinya rendah akan selalu memberikan hasil yang menyimpang dari nilai benar (Siregar et al. 2018; Verbrugge and Huisman 2015).

Presisi merupakan suatu ukuran yang menunjukkan kedekatan hasil dari setiap pengulangan pemeriksaan pada sampel yang sama. Presisi disajikan dalam bentuk impresisi yang dinyatakan dalam ukuran koefisien variasi (KV/CV). Hasil yang diperoleh dari perhitungan dapat mempersentasikan presisi pada tempat percobaan dimana bertujuan untuk memverifikasi bahwa metode akan menghasilkan hasil yang sama pada fasilitas tempat yang berbeda (Siregar et al. 2018; Verbrugge and Huisman 2015). 
Total Error (TE) atau Total

Analytical Error (TAE) merupakan

kesalahan dari keseluruhan dalam hasil tes yang dikaitkan dengan ketidaktepatan (Bias) dan ketidaktelitian (CV) yang mana adalah kombinasi dari kesalahan acak dan kesalahan sistematik. Konsep kesalahan diasumsikan bahwa perbedaan antara hasil yang diukur dan nilai sebenarnya atau nilai kuantitas referensi dapat dihitung. Jika total error dari metode tes lebih besar dari total allowable error maka ada masalah dari pemeriksaan tersebut. Total error allowable merupakan perbedaan hasil yang akan memicu tindakan medik jika \% CV didapatkan dibawah regulasi CLIA untuk beberapa parameter darah lengkap (Little et al. 2011).

ISO $\quad 15189$ guide $\quad 5.9 .1$ menyatakan bahwa laboratorium harus memiliki prosedur untuk memastikan bahwa personil yang berwenang untuk mengkaji hasil pemeriksaan, mengevaluasi pengendalian mutu internal dan jika memungkinkan di evaluasi terhadap informasi klinis yang tersedia dan hasil pemeriksaan sebelumnya sebelum dikeluarkan. Dalam penelitian ini, Quality control juga dilakukan oleh peneliti dengan memeriksa bahan kontrol yang telah diketahui kadarnya yaitu level normal dan membandingkan hasil pemeriksaan alat dengan rentang kadar bahan kontrol tersebut. Quality control ini bertujuan agar mendapatkan hasil pemeriksaan laboratorium yang bermutu dan dapat dipercaya serta memastikan bahwa nilai tersebut dapat diterima (acceptable true value), sehingga setiap tahap pemeriksaan laboratorium harus dikendalikan untuk meminimalisir kesalahan yang dapat terjadi (Praptomo 2018; Siregar et al. 2018).

Laboratorium medis perlu melakukan penilaian antara dua metode pengukuran, jika akan melakukan penggantian metode/ instrument pemeriksaan, evaluasi metode/ instrument baru atau alternatif, atau ingin melakukan penyelarasan antara dua metode/ instrument. Validasi pengukuran klinis harus mencakup semua prosedur yang menunjukkan bahwa metode tertentu yang digunakan untuk pengukuran kuantitatif dari variabel yang bersangkutan reliable dan reproducible. Pengukuran variabel selalu menyiratkan beberapa tingkat kesalahan. Ketika dua metode dibandingkan, tidak ada yang memberikan pengukuran yang benarbenar tepat, sehingga mungkin menarik untuk mencoba menilai tingkat agreement (Giavarina 2015). 
Metode statistik yang digunakan dalam penelitian ini yaitu analisis Bland Altman. Analisis tersebut digunakan untuk menilai kesesuaian dari dua pengukuran dengan perbedaan rerata pengukuran yang akan menggambarkan bias/akurasi $(\mathrm{d} \%)$ yang mungkin terjadi pada dua pengukuran. Analisis Bland Altman merupakan cara sederhana untuk mengevaluasi bias antara perbedaan rata-rata dan untuk memperkirakan interval kesepakatan, dimana digunakan batas kesepakatan yaitu 95\% yang disebut dengan LOA (limit of agreements). Limit of agreements tersebut dihitung menggunakan mean dan standar deviasi dari perbedaan atara dua pengukuran. Grafik yang dihasilkan adalah sebaran plot XY, di mana sumbu Y menunjukkan perbedaan antara dua pengukuran berpasangan (AB) dan sumbu $\mathrm{X}$ mewakili rata-rata ukuran ini $((\mathrm{A}+\mathrm{B}) / 2)$. Dengan kata lain, perbedaan dari dua pengukuran berpasangan diplot terhadap rata-rata dari dua pengukuran. Metode ini hanya menentukan interval agreement tidak disebutkan apakah batasan tersebut dapat diterima atau tidak. Batas yang dapat diterima harus ditentukan berdasarkan kebutuhan klinis, pertimbangan biologis atau tujuan lain (Giavarina 2015).
Berdasarkan Gambar 1 yaitu grafik dari hasil analisis Bland Altman menggambarkan hubungan selisih pengukuran nilai dari tiap parameter yang diperiksa dengan menggunakan Abacus 3 dan Sysmex KX 21 terhadap rata-ratanya. Pada grafik tersebut terdapat garis merah yang menunjukkan bias atau mean difference, sedangkan untuk 2 garis hijau menunjukkan Upper Limit dan Lower Limit. Digunakan Limits of agreements berupa 1.96 (nilai Z 95\%), sehingga perhitungan untuk Upper Limit dan Lower Limit diperoleh dengan cara mengalikan standar deviasi dengan $1.96 \pm$ dari mean differences tersebut. Pada grafik tersebut tergambarkan sebaran plot yang akan diperoleh. Plot tersebut berupa titik dalam grafik. Titik tersebut menggambarkan pengamatan diantara dua metode pengukuran yang dilakukan, dimana titik tersebut harus berada di dalam LOA (limit of agreement) dengan interval kesepakatan yaitu 95\%. Jika titik tersebut berada di dalam upper limit dan lower limit berarti terdapat pengamatan yang sama diantara dua metode tersebut, sedangkan jika titik berada di luar upper limit dan lower limit maka terdapat pengamatan yang berbeda dari pengamatan atau dianggap sebagai outlier (Bland and Altman 2018; Giavarina 2015). 


\section{Berdasarkan gambar 1, parameter yang diperiksa didapat nilai}

didapatkan hasil pada parameter eritrosit, leukosit dan hematokrit terdapat satu pengamatan atau titik dalam grafik yang berada diluar Upper Limit. Pada parameter trombosit terdapat satu pengamatan atau titik dalam grafik yang berada diluar Lower Limit, sedangkan untuk parameter hemoglobin terdapat dua pengamatan atau titik dalam grafik yang berada diluar Upper Limit. Adanya titik dalam grafik yang berada di dalam upper limit dan lower limit berarti terdapat pengamatan yang sama diantara dua metode tersebut, sedangkan titik yang berada di luar upper limit dan lower limit maka terdapat pengamatan yang berbeda dari pengamatan atau dianggap sebagai outlier. Jika outlier yang terlihat tidak melebihi dua titik atau plot, hal tersebut masih masuk dalam kriteria keberterimaan.

Berdasarkan hasil pengukuran yang diperoleh dari pemeriksaan yang dilakukan menggunakan Hematology analyzer Diatron Abacus 3 terhadap Sysmex KX 21, didapatkan hasil yaitu: nilai akurasi yang lebih kecil dari nilai benar pada kit insert pada parameter eritrosit, trombosit, hemoglobin dan hematokrit, sedangkan untuk leukosit nilai akurasi yang diperoleh lebih besar. CV hitung yang diperoleh pada kelima yang lebih besar dari CV pada kit insert. Nilai TE yang lebih besar dibandingkan dengan TEA terdapat pada parameter eritrosit, leukosit, hemoglobin dan hematokrit, sedangkan untuk trombosit TE lebih kecil dari TEA. Hal tersebut dapat disebabkan oleh kesalahan acak maupun kesalahan sistematis. Secara umum kesalahan acak disebabkan oleh beberapa faktor yang secara acak berpengaruh pada proses pengukuran, kesalahan bersumber dari variasi yang terjadi diluar kendali tenaga laboratorium yang melakukan pengukuran, seperti: instrumen yang kurang stabil, variasi temperatur, reagen, kalibarasi, saat pencampuran, waktu inkubasi sampel, factor analis yang memeriksa, maupun tegangan listrik dan kondisi lingkungan. Kesalahan acak berhubungan dengan presisi/ketelitian. Kesalahan sistematik disebabkan oleh beberapa faktor yang terjadi secara sistematis yang mempengaruhi hasil pengukuran dan dapat memberikan bias/akurasi hasil pengukuran yang dapat bernilai positif atau negatif. Kesalahan ini disebabkan oleh mutu reagen yang rendah, kelemahan metode pemeriksaan, blanko sampel, blanko reagen kurang, dan mutu reagen kalibrasi kurang baik (Siregar et al., 2018). 
Nilai dari pemeriksaan yang dilakukan menggunakan Abacus 3 cenderung lebih meningkat dibandingkan Sysmex KX 21. Hali ini juga dapat dilihat dari nilai bias bernilai positif (Tabel 1). Hasil dari pemeriksaan spesimen darah lengkap parameter eritrosit, leukosit, trombosit, hemoglobin dan hematokrit dapat meningkat karena dapat disebabkan oleh beberapa faktor yaitu jumlah spesimen yang terhisap dari alat Abacus 3 lebih banyak yaitu $100 \mu$ l, sedangkan untuk Sysmex KX 21 yaitu hanya $50 \mu$ l pada mode whole blood. Pemindahan spesimen darah K3EDTA ke tabung lainnya juga dapat mempengaruhi hasil yang disebabkan karena kurang homogenisasi atau volume yang kurang sehingga jumlah sel yang terhitung oleh alat tidak menggambarkan kondisi pasien yang sebenarnya. Sysmex KX 21 merupakan jenis alat open tube, kesalahan dapat terjadi pada saat menghisap sampel jika jarum tidak masuk penuh ujungnya sampai dasar tabung. Untuk alat close tube yaitu Abacus 3 kesalahan dapat juga terjadi serupa dan kurangnya volume yang diminta oleh alat, sehingga tidak memenuhi kriteria dengan jumlah volume darah minimum $1 \mathrm{ml}$ (Abacus 3 n.d.; Nurrachmat 2005; XN-450/XN-430 n.d.).
Menurut pedoman verifikasi dan validasi oleh ICSH dan CLSI disebutkan bahwa untuk melakukan evaluasi terhadap Hematology analyzer yang akan dibandingkan dengan Hematology analyzer lainnya, waktu pengambilan darah dan pengukuran harus dipantau selama proses. Pengujian sampel harus dilakukan dalam waktu 4 hingga 8 jam setelah sampling, sehingga sampel yang akan dibandingkan hasilnya akan sama baiknya (Verbrugge and Huisman 2015). Beberapa hal yang dapat mempengaruhi pemeriksaan yaitu pada penelitian Cinthia, Agnes tentang perbedaan morfologi eritrosit pada spesimen darah $\mathrm{K}_{3}$ EDTA yang segera diperiksa dan ditunda selama 3 jam didapatkan hasil bahwa ada perbedaan morfologi eritrosit, karena selama penyimpanan sel-sel darah akan mengalami perubahan biokimiawi, biomekanis, dan reaksi imunologis, menyebabkan terjadinya kerusakan struktural/morfologis yang dikenal sebagai storage lesion (Cinthia, Sukeksi, and Santoso 2018). Hasil pemeriksaan leukosit yang berbeda menggunakan Abacus 3 dan Sysmex KX 21 juga dapat disebabkan oleh berbagai faktor yaitu suhu dan lama penyimpanan, alat yang digunakan, faktor pemeriksa maupun reagen yang digunakan. Dalam jurnal Darmadi dan Dewi tentang perbedaan 
jumlah leukosit darah edta diperiksa segera dan ditunda 2 jam didapatkan hasil bahwa hasilnya normal menurun namun tidak ada perbedaan bermakna secara statistik. Oleh karena itu, lamanya pemeriksaan juga dapat berpengaruh pada hasil pemeriksaan yang dilakukan karena spesimen yang didapat oleh peneliti tidak langsung diperiksa. Dalam Menkes 37 tahun 2012 juga disebutkan bahwa maksimal penyimpanan darah edta terhadap jumlah leukosit yaitu 2 jam pada suhu kamar (Darmadi and Permatasari 2018). Waktu pemeriksaan antara Abacus 3 dan Sysmex KX 21 berbeda sehingga menghasilkan nilai evaluasi analitik yang cukup beragam namun masih dalam batas yang diizinkan.

Pada hasil pemeriksaan jumlah trombosit memberikan hasil yang bervariasi menggunakan Abacus 3 dibanding dengan hasil menggunakan alat Sysmex KX 21. Dalam jurnal Zini, $\mathrm{G}$ tentang stabilitas parameter hitung darah lengkap dengan penyimpanan: menuju spesifikasi yang ditentukan untuk berbagai diagnostik disebutkan bahwa adanya pembentukan PLT raksasa dapat menyebabkan hasil meningkat palsu karena adanya fragmen. Namun, jika spesimen hitung PLT disimpan pada suhu $4^{0} \mathrm{C}$ maka spesimen akan stabil hingga 24 jam atau bahkan
72 jam, meskipun dalam beberapa penelitian menunjukkan bahwa terjadi penurrunan dari waktu ke waktu. Dalam penelitian Lasmilatu tentang perbedaan hitung jumlah trombosit segera diperiksa dengan jumlah trombosit setelah ditunda 15 menit, 45 menit, dan 60 menit pada darah EDTA didapatkan hasil bahwa ada perbedaan yang bermakna pada pemeriksaan tersebut. Suhu dan waktu penyimpanan sangat berpengaruh terhadap spesimen darah EDTA, jika pemeriksaan melebihi batas pemeriksaan maka akan terjadi perubahan baik kuantitas maupun kualitas pada beberapa sel-sel darah (Lasmilatu 2019; Zini 2014).

Pada penelitian Sriwati tentang perbedaan kadar hemoglobin pada sampel yang segera diperiksa dan ditunda 3 jam pada suhu kamar didapatkan hasil ada perbedaan pada hasil pemeriksaan. Darah yang dibiarkan pada suhu kamar selama beberapa jam mengakibatkan perubahan profil eritrosit yang dikenal storage lesion yaitu ukuran eritrosit mengecil. Perubahan profil eritrosit yang menjadi ukuran mengecil menyebabkan darah encer sehingga mempengaruhi kadar hemoglobin. Nilai hematokrit yang meningkat dapat disebabkan karena peningkatan retikulosit atau hasil WBC yang akan dihitung sebagai sel darah merah. Untuk 
hasil Hct yang sangat rendah dapat disebabkan karena tingkat MCV yang menurun akibat mikrositosis, dimana sel tersebut akan dikenali sebagai leukosit. Diperlukan penanganan sampel yang hati-hati, terutama saat pencampuran untuk menghindari pembacaan yang salah, karena parameter hematokrit dibaca bersama dengan parameter lainnya dalam satu sampel yang sama. Penurunan dari jumlah hematokrit sejalan dengan penelitian yang dilakukan oleh Yumaroh tentang perbedaan kadar hematokrit darah EDTA yang disimpan suhu kamar dan suhu lemari pendingin selama 6 jam dan 18 jam, didapatkan bahwa nilai hematokrit akan mengalami penurunan yang stabil pada 6 jam pertama tetapi tidak memberikan perbedaan secara signifikan (Sriwati 2018; XN-450/XN430 n.d.; Yumaroh, Ariyadi, and Faruq 2018).

Analisis regresi merupakan analisis untuk melihat apakah antara dua variabel atau lebih memiliki pengaruh/ hubungan atau tidak, yang mana akan bermakna apabila pengaruh antara variabel-variabel didasarkan pada kerangka teori terkuat. Linearitaas menunjuk pada pengertian adanya hubungan yang linear antara dua sebaran data variabel (dependen dan independen) atau dapat dikatakan bahwa sebaran data kedua variabel mempunyai hubungan yang linear. Linearitas adalah hubungan yang linear antarvariabel artinya setiap adanya perubahan yang terjadi pada satu variable akan diikuti oleh perubahan dengan besaran yang sejajar pada variable lainnya. Uji linearitas garis regresi mengasumsikan bahwa hubungan atau sebaran skor yang akan diolah garis regresinya linear sehingga begitu saja menggunakan parameter garis regresi $y=a+b X$. $y$ adalah yang akan diprediksi, a sebagai bilangan konstan, b sebagai koefisien predictor, dan $\mathrm{X}$ adalah variabel prediktor (Kadir 2017; Nurgiyantoro and Dkk 2017).

Gambar 2, diperoleh prediksi nilai pada parameter yang diperiksa menggunakan Hematology analyzer Abacus 3 terhadap Sysmex KX 21 sudah cukup baik untuk menggambarkan hubungan keduanya tanpa mempertimbangkan variabel lain yang mempengaruhi serta kedua alat tersebut memiliki hubungan positif. Hal tersebut terlihat dari nilai $\mathrm{R}^{2}$ dan juga nilai korelasi (R) mendekati nilai 1. Hubungan positif pada kedua alat menunjukkan bahwa kenaikan nilai pengukuran menggunakan Abacus 3 diikuti dengan kenaikan nilai pengukuran menggunakan Sysmex KX 
21 (Kadir 2017; Nurgiyantoro and Dkk 2017).

Gambar 2.a diperoleh prediksi (y) dengan konstanta sebesar 117902.611 dan koefisien sebesar 0.993. Nilai Konstanta sebesar 117902.611 menunjukkan bahwa saat $\mathrm{x}=0$ yang berarti belum dilakukan pengukuran terhadap eritrosit, diperoleh bahwa alat ukur Hematology Analyzer Abacus 3 mempunyai nilai yang lebih besar sejumlah 117902.611 daripada alat ukur Sysmex KX 21. Nilai Koefisien sebesar 0.993 menunjukkan bahwa nilai eritrosit yang diukur dengan menggunakan alat ukur Hematology Analyzer Abacus 3 (y) akan memiliki nilai sebesar 0.993 kali lebih besar daripada nilai eritrosit yang diukur dengan menggunakan alat ukur Sysmex KX 21. Nilai $R^{2}$ sebesar 0.942 menunjukkan bahwa prediksi nilai Eritrosit dari Hematology Analyzer Abacus 3 terhadap Sysmex KX 21 sudah cukup baik untuk menggambarkan hubungan keduanya tanpa mempertimbangkan variabel lain yang mempengaruhi. Nilai korelasi (R) sebesar 0.97 menunjukkan bahwa pengukuran menggunakan Hematology Analyzer Abacus 3 dan Sysmex KX 21 memiliki hubungan yang positif. Berarti kenaikan nilai pengukuran menggunakan Abacus 3 diikuti dengan kenaikan nilai pengukuran menggunakan Sysmex KX 21(Kadir 2017; Nurgiyantoro and Dkk 2017).

Gambar 2.b diperoleh prediksi (y) dengan konstanta sebesar -105.974 dan koefisien sebesar 1.095. Nilai Konstanta sebesar -105.974 menunjukkan bahwa saat $\mathrm{x}=0$ yang berarti belum dilakukan pengukuran terhadap leukosit, diperoleh bahwa alat ukur Hematology Analyzer Abacus 3 mempunyai nilai yang lebih kecil sejumlah 105.974 daripada alat ukur Sysmex KX 21. Nilai Koefisien sebesar 1.095 menunjukkan bahwa nilai leukosit yang diukur dengan menggunakan alat ukur Hematology Analyzer Abacus 3 (y) akan memiliki nilai sebesar 1.095 kali lebih besar daripada nilai leukosit yang diukur dengan menggunakan alat ukur Sysmex $\mathrm{KX}$ 21. Nilai $\mathrm{R}^{2}$ sebesar 0.996 menunjukkan bahwa prediksi nilai leukosit dari Hematology Analyzer Abacus 3 terhadap Sysmex KX 21 sudah cukup baik untuk menggambarkan hubungan keduanya tanpa mempertimbangkan variabel lain yang mempengaruhi. Nilai korelasi (R) sebesar 0.998 menunjukkan bahwa pengukuran menggunakan Hematology Analyzer Abacus 3 dan Sysmex KX 21 memiliki hubungan yang positif. Berarti kenaikan nilai pengukuran menggunakan Abacus 3 diikuti dengan kenaikan nilai pengukuran 
menggunakan Sysmex KX 21 (Kadir 2017; Nurgiyantoro and Dkk 2017).

Gambar 2.c diperoleh prediksi (y) dengan konstanta sebesar 26946.849 dan koefisien sebesar 0.840. Nilai Konstanta sebesar 26946.849 menunjukkan bahwa saat $\mathrm{x}=0$ yang berarti belum dilakukan pengukuran terhadap trombosit, diperoleh bahwa alat ukur Hematology Analyzer Abacus 3 mempunyai nilai yang lebih besar sejumlah 26946.849 daripada alat ukur Sysmex KX 21. Nilai Koefisien sebesar 0.840 menunjukkan bahwa nilai trombosit yang diukur dengan menggunakan alat ukur Hematology Analyzer Abacus 3 (y) akan memiliki nilai sebesar 0.840 kali lebih besar daripada nilai trombosit yang diukur dengan menggunakan alat ukur Sysmex KX 21. Nilai $R^{2}$ sebesar 0.956 menunjukkan bahwa prediksi nilai trombosit dari Hematology Analyzer Abacus 3 terhadap Sysmex KX 21 sudah cukup baik untuk menggambarkan hubungan keduanya tanpa mempertimbangkan variabel lain yang mempengaruhi. Nilai korelasi (R) sebesar 0.978 menunjukkan bahwa pengukuran menggunakan Hematology Analyzer Abacus 3 dan Sysmex KX 21 memiliki hubungan yang positif. Berarti kenaikan nilai pengukuran menggunakan Abacus 3 diikuti dengan kenaikan nilai pengukuran menggunakan Sysmex KX 21(Kadir 2017; Nurgiyantoro and Dkk 2017).

Gambar 2.d diperoleh prediksi (y) dengan konstanta sebesar 0.953 dan koefisien sebesar 0.947. Nilai Konstanta sebesar 0.953 menunjukkan bahwa saat $\mathrm{x}=0$ yang berarti belum dilakukan pengukuran terhadap hemoglobin, diperoleh bahwa alat ukur Hematology Analyzer Abacus 3 mempunyai nilai yang lebih besar sejumlah 0.953 daripada alat ukur Sysmex KX 21. Nilai Koefisien sebesar 0.947 menunjukkan bahwa nilai hemoglobin yang diukur dengan menggunakan alat ukur Hematology Analyzer Abacus 3 (y) akan memiliki nilai sebesar 0.947 kali lebih besar daripada nilai hemoglobin yang diukur dengan menggunakan alat ukur Sysmex KX 21. Nilai $\mathrm{R}^{2}$ sebesar 0.952 menunjukkan bahwa prediksi nilai hemoglobin dari Hematology Analyzer Abacus 3 terhadap Sysmex KX 21 sudah cukup baik untuk menggambarkan hubungan keduanya tanpa mempertimbangkan variabel lain yang mempengaruhi. Nilai korelasi (R) sebesar 0.975 menunjukkan bahwa pengukuran menggunakan Hematology Analyzer Abacus 3 dan Sysmex KX 21 memiliki hubungan yang positif. Berarti kenaikan nilai pengukuran menggunakan Abacus 3 diikuti dengan kenaikan nilai pengukuran 
menggunakan Sysmex KX 21 (Kadir 2017; Nurgiyantoro and Dkk 2017).

Gambar 2.e diperoleh prediksi (y) dengan konstanta sebesar 0.503 dan koefisien sebesar 0.970. Nilai Konstanta sebesar 0.503 menunjukkan bahwa saat $\mathrm{x}=0$ yang berarti belum dilakukan pengukuran terhadap hematokrit, diperoleh bahwa alat ukur Hematology Analyzer Abacus 3 mempunyai nilai yang lebih besar sejumlah 0.503 daripada alat ukur Sysmex KX 21. Nilai Koefisien sebesar 0.970 menunjukkan bahwa nilai hematokrit yang diukur dengan menggunakan alat ukur Hematology Analyzer Abacus 3 (y) akan memiliki nilai sebesar 0.970 kali lebih besar daripada nilai hematokrit yang diukur dengan menggunakan alat ukur Sysmex KX 21. Nilai $R^{2}$ sebesar 0.936 menunjukkan bahwa prediksi nilai hematokrit dari Hematology Analyzer Abacus 3 terhadap Sysmex KX 21 sudah cukup baik untuk menggambarkan hubungan keduanya tanpa mempertimbangkan variabel lain yang mempengaruhi. Nilai korelasi (R) sebesar 0.967 menunjukkan bahwa pengukuran menggunakan Hematology Analyzer Abacus 3 dan Sysmex KX 21 memiliki hubungan yang positif. Berarti kenaikan nilai pengukuran menggunakan Abacus 3 diikuti dengan kenaikan nilai pengukuran menggunakan Sysmex KX 21(Kadir 2017; Nurgiyantoro and Dkk 2017).

Keterbatasan dalam penelitian ini yaitu jarak waktu antara pengambilan sampel dengan pemeriksaan spesimen menggunakan Abacus 3 terdapat 9 sampel yang melebihi 8 jam jika dibandingkan dengan Sysmex KX21. Menurut pedoman verifikasi dan validasi oleh ICSH dan CLSI disebutkan bahwa untuk melakukan evaluasi terhadap Hematology Analyzer yang akan dibandingkan dengan Hematology Analyzer lainnya, waktu pengambilan darah dan pengukuran harus dipantau selama proses. Pengujian sampel harus dilakukan dalam waktu 4 hingga 8 jam setelah sampling, sehingga sampel yang akan dibandingkan hasilnya akan sama baiknya (Verbrugge dan Huisman, 2015). Pemindahan spesimen uji tidak dilakukan oleh peneliti dan peneliti tidak dapat melakukan standby di laboratorium karena keterbatasan jumlah pasien yang melakukan pemeriksaan.

\section{KESIMPULAN}

Kesimpulan dari penelitian ini adalah hasil pengukuran parameter hematologi (jumlah eritrosit, leukosit, hemoglobin, hematokrit, trombosit) pada alat Diatron Abacus 3 linier terhadap Sysmex KX sebagai pembanding. Pengukuran parameter hematologi (jumlah eritrosit, 
leukosit, hemoglobin, hematokrit, trombosit) menggunakan alat Diatron Abacus 3 di Laboratorium Hematologi Poltekkes Kemenkes Kalimantan Timur dapat diterima dan dapat dipercaya sehingga dapat digunakan untuk pembelajaran praktik, penelitian, maupun pelayanan terhadap masyarakat.

\section{DAFTAR PUSTAKA}

Abacus 3, Panduan Operator. Hematology Analyzer Abacus 3. Diapro Health Care Supplies.

Ayuningtyas, Yuniar. 2018. Tugas Akhir "Profil Pemantapan Mutu Alat Hematlogy Analyzer Abbott Ruby Di Instalasi Patologi Klinik RSUD.DR.Moerwadi Di Surakarta." Setia Budi Surakarta.

Bland, J. MARTIN, and DOUGLAS G. Altman. 2018. STATISTICAL METHODS FOR ASSESSING AGREEMENT BETWEEN TWO METHODS OF CLINICAL MEASUREMENT. The Lancet 62(7): 307-10.

Cinthia, Agnes, Andri Sukeksi, and Budi Santoso. 2018. PERBEDAAN MORFOLOGI ERITROSIT PADA SPESIMEN DARAH K3EDTA YANG SEGERA DIPERIKSA DAN DITUNDA SELAMA 3 JAM. Muhammadiyah Semarang.

Darmadi, and Dewi Permatasari. 2018. Perbedaan Jumlah Leukosit Darah Edta Diperiksa Segera Dan Ditunda 2 Jam. Klinikal Sains 6(2): 30-36.
Departemen Kesehatan RI. 2008. Pedoman Praktik Laboratorium Yang Benar(Good Laboratory Practice).

Giavarina, Davide. 2015. Understanding Bland Altman Analysis. Biochemia Medica 25(2): 141-51.

Kadir. 2017. Statistik Terapan:Konsep, Contoh Dan Analisis Data Dengan Program SPSS/ Lisrel Dalam Penelitian. $\quad 3 r d$ ed. Depok: Rajawali Pers.

Lasmilatu, Maria Veneranda. 2019. PERBEDAAN HITUNG JUMLAH TROMBOSIT SEGERA DIPERIKSA DENGAN JUMLAH TROMBOSIT SETELAH DITUNDA 15 MENIT, 30 MENIT, 45 MENIT DAN 60 MENIT PADA DARAH EDTA KARYA. Poltekkes Kemenkes Kupang.

Little, Randie R., Erna Lenters-Westra, Curt L. Rohlfing, and Robbert Slingerland. 2011. Gross Overestimation of Total Allowable Error Based on Biological Variation. Clinical Chemistry 57(9): 1334-36.

Nirwani, Tri Hartiti, and Zulfikar Husni Faruq. 2018. Analisis Akurasi Dan Presisi Alat Hematology Analyzer Abx Pentra Xl 80 Di Laboratorium Rumah Sakit Roemani Muhammadiyah Semarang. Analisis akurasi dan presisi alat hematology analyzer abx pentra $x l$ 80 di laboratorium rumah sakit roemani muhammadiyah semarang.

Nurgiyantoro, Burhan, and Dkk. 2017. Statistik Terapan Untuk Penelitian Ilmu Sosial. Yogyakarta: Gadjah Mada University Press. 
Nurrachmat, Harun. 2005. Perbedaan Jumlah Eritrosit, Leukosit, Dan Trombosit Pada Pemberian Antikoagulan EDTA Konvensional Dengan EDTA Vacutainer. In Tesis. Bagian Patologi Klinik FK Undip, Semarang, .

Praptomo, Agus Joko. 2018. Pengendalian Mutu Laboratorium Medis. In Yogyakarta: Deepublish.

Siregar, Maria Tuntun, Wieke Sri Wulan, Doni Setiawan, and Anik Nuryati. 2018. Bahan Ajar Teknologi Laboratorium Medik: Kendali Mutu. In Badan Pengembangan dan Pemberdayaan Sumber daya Manusia Kementrian Kesehatan RI.

Sriwati, Cicik. 2018. Perbedaan Kadar Hemoglobin Pada Sampel Yang Segera Diperiksa Dan Ditunda 3 Jam. Universitas Muhammadiyah Semarang.
Verbrugge, Sue Ellen, and Albert Huisman. 2015. Verification and Standardization of Blood Cell Counters for Routine Clinical Laboratory Tests. Clinics in Laboratory Medicine 35(1): 18396.

XN-450/XN-430, Sysmex. Sysmex XN450/XN-430 Automated Hematology Analyzer CLSI Procedure. In Document Number 1235-LSS, Rev.4, September 2018.

Yumaroh, Siti, Tulus Ariyadi, and Zulfikar Husni Faruq. 2018. PERBEDAAN KADAR HEMATOKRIT DARAH EDTA DISIMPAN SUHU KAMAR DAN SUHU LEMARI PENDINGIN SELAMA 6 JAM DAN 18 JAM. Universitas Muhammadiyah Semarang.

Zini, G. 2014. Stability of Complete Blood Count Parameters with Storage: Toward Defined Specifications for Different Diagnostic Applications. International Journal of Laboratory Hematology 36(2): 111-13. 